\title{
The Politics of Print in the Dutch Golden Age: The Ommelander Troubles (c. 1630-168o)
}

\author{
Arthur der Weduwen
}

In December 1642, alarming reports spread throughout the Dutch Republic. A military incursion in Groningen, in the north-east of the country, ravaged the countryside. A small but ferocious band of soldiers, some seventy in total, tore through villages and farms, plundering, raping, taking hostages and throwing pregnant women off a dyke. Although the Dutch Republic was a state that depended on commerce, it was also a country that was almost continually at war throughout the seventeenth century. However, this episode of warfare was not part of a conflict between the Dutch and a foreign power, but between contesting political factions within the Dutch state. The December raid in Groningen was not an account of a foreign invasion, but of an instance of violence committed by Dutch soldiers against Dutch citizens. This was one sad, but recurring event, which took place as part of the Ommelander Troubles.

This particular instance of violence has come down to us thanks to a publication by the Council of Ommelanden, the representative assembly of nobles and landholders of the Groningen countryside. On 9 December 1642, they published a placard against the city of Groningen, accusing the magistrates of that city of sponsoring the vicious raid. In eight short paragraphs, the Ommelanders claimed that Rudolph Schuringh, one of the magistrates of the city, had led the excursions into Ommelanden territory, and that he had employed a company of garrisoned soldiers in the pay of the States General, thereby using 'weapons of the generality ... against their own lords and pay masters.' ${ }^{1}$ At the end of the placard, the Council of Ommelanden called upon their citizens to capture Schuringh, and answer the call to arms to protect their 'fatherland' whenever church bells were rung (see figure 7.1).

The Ommelanden broadsheet is a chilling text, portraying some of the horrors inflicted upon the Groningen countryside by a band of marauding troops. It is also a remarkable piece of official print, representing a public attack by

1 De Heeren van den Omme-Landen tusschen d'Eems ende Lauwers, doen te weten: alsoo Rudolph Schuyrinck heeft verstoutet deselve Omlanden te invaderen ([Groningen: s.n., 1642]), UsTC 1122292. 


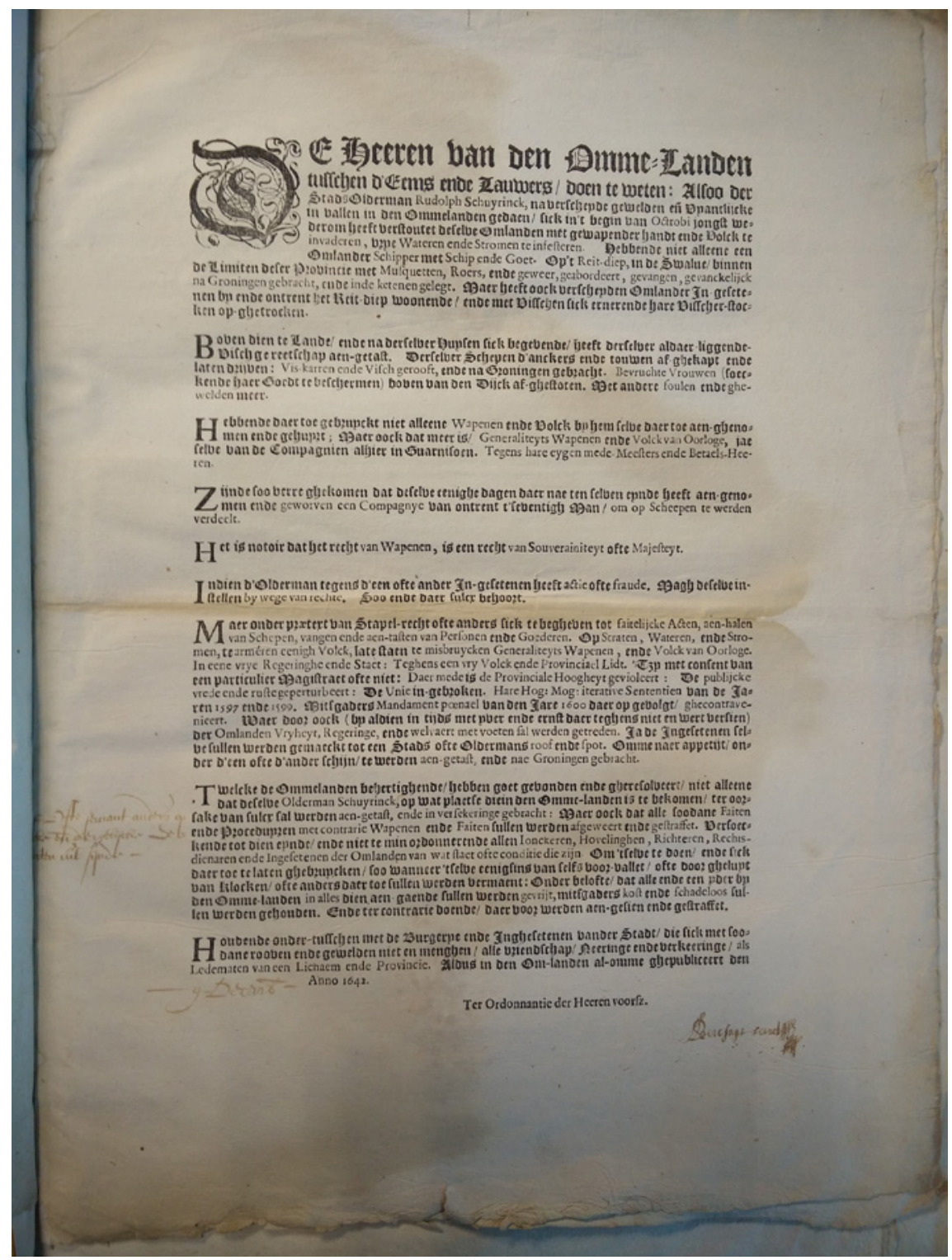

FIGURE 7.1 The Ommelander broadsheet of 9 December 1642, condemning the attacks of the Groningen magistrate Rudolf Schuringh GRONINGER ARCHIEVEN, GRONINGEN 
one legal authority upon another. For much of the seventeenth century, the northern Dutch province of Groningen was consumed by a turbulent conflict between the two constituent parts of the provincial States. The two authoritiesthe magistrates of Groningen and the rural Council of Ommelanden - regularly plunged their province into civil war. This struggle was violent, fought by arms and unlawful arrests; but it was also a war of words, dominated by repeated volleys of printed declarations, resolutions and ordinances. Far from appealing only to their own supporters, both sides continually addressed the citizens of their opponents, and made concerted efforts to dominate the public sphere. Printed declarations were proclaimed and affixed provocatively in contended political spaces. Printers producing official ordinances were intimidated, and their equipment was confiscated. Both the magistrates and the Ommelanders claimed indignantly (and repeatedly) that their authority was undermined by printed libels and placards issued by their opponents; and both authorities adopted the same public strategy to air their grievances. Every stage of the conflict involved a renewed round of declarations and counter-declarations, as neither side was willing to grant their opponent the last word.

The municipal and provincial archives in Groningen contain multiple stacks of official print, a corpus of a couple of hundred extant printed placards and pamphlets issued by the two authorities, devoted to this bitter and persistent public struggle at the heart of the Dutch Republic. ${ }^{2}$ I first encountered these sources during my $\mathrm{PhD}$ research, investigating the communication practices of Dutch authorities in the seventeenth century. ${ }^{3}$ I initially conceived this study of political communication as an exchange between authorities and their citizens. But it soon became clear that Dutch authorities published and disseminated official letters, declarations, resolutions and ordinances that did not directly address their citizens, but rather attacked or insulted their domestic opponents. This involved an exchange between two opposing legal authorities; an act of communication, which would, in theory, be maintained in the closed circuit of political decision-making that excluded the average Dutch citizen. It is well established that Dutch authorities made real efforts to withhold political information from the public. Their aversion to the publication of political pamphlets, as evidenced by numerous placards and ordinances targeting

2 Groninger Archieven, Groningen (GAG), Ommelander Archieven, inv. 374, 758-888; Staten Archief, inv. 475, 866-867; Archief van de stad, inv. 298-313.

3 This article is predominantly based on a chapter of my $\mathrm{PhD}$ thesis, defended at the University of St Andrews in 2018 and entitled Selling the Republican Ideal. State Communication in the Dutch Golden Age. 
seditious print, has also been frequently noted. ${ }^{4}$ The reverse, however, has not yet been appreciated: that the authorities of the seventeenth-century Dutch Republic were very finely attuned to the benefit of conducting political business before the eyes of their citizens whenever it suited them to do so. In this article I wish to sketch out why this phenomenon has not received the scholarly attention that it deserves, and how we can refine our understanding of the interactions between political elites and print culture in the Dutch Republic. The remarkable episodes that took place as part of the Ommelander Troubles offer an ideal avenue to explore the politicisation of print during the Dutch Golden Age, and allow us to incorporate a more nuanced perspective on the importance of public communication to our conception of the early modern period.

\section{Public Politics in the Dutch Republic}

The Dutch Republic, like most early modern states, was an undemocratic political system. In theory, almost all inhabitants of the Dutch Republic had no political voice. The state was dominated by a tiny, exclusive class of regents, who made up the seven sovereign provincial States of Gelderland, Holland, Zeeland, Utrecht, Friesland, Overijssel and Groningen. ${ }^{5}$ Their prerogative of policy-making could not be formally questioned. The regents negotiated with one another behind closed doors in city hall chambers and the rooms of the central government complex in The Hague, the Binnenhof.

4 Ingrid Weekhout, Boekencensuur in de Noordelijke Nederlanden: de vrijheid van drukpers in de zeventiende eeuw (Den Haag: Sdu, 1998), especially pp. 23-86, 371-39o; Simon Groenveld, 'The Mecca of Authors? States Assemblies and Censorship in the Seventeenth-Century Dutch Republic', in A.C. Duke and C.A. Tamse (eds.), Too Mighty to be Free: Censorship and the Press in Britain and the Netherlands (Zutphen: De Walburg Pers, 1987), pp. 63-86, here p. 74; Guido de Bruin, Geheimhouding en verraad:De geheimhouding van staatszaken ten tijde van de Republiek (1600-1750) (Den Haag: Sdu, 1991), pp. 355-443; Eric Platt, Britain and the Bestandstwisten. The Causes, Course and Consequences of British Involvement in the Dutch Religious and Political Disputes of the Early Seventeenth Century (Gottingen: Vandenhoeck \& Ruprecht, 2015), p. 158.

5 The best overviews are Robert Fruin, Geschiedenis der staatsinstellingen in Nederland tot den val der Republiek, ed. H.T. Colenbrander (Den Haag: Martinus Nijhoff, 1901) and S.J. Fockema Andreae, De Nederlandse Staat onder de Republiek (Amsterdam: NoordHollandsche Uitgevers Maatschappij, 1985). 
Secrecy was the assumed norm in government business, but it was never perfectly practised. ${ }^{6}$ The confederal composition of the Dutch Republic ensured that a regular flow of political information was maintained between and within the seven provinces. Without the consent of all provinces, federal policy-making could cease. Within the provinces, the sentiments of any of the voting cities, nobles or factions would have to be taken into consideration to arrive at a consensus; it was essential that all political participants shared their opinions with one another. The representatives of these provincial assemblies had to confer with their own municipal councils, travelling back and forth to decide upon negotiation strategies and potential concessions. The complex layers of governance in the Dutch Republic meant that Dutch authorities 'were never able to secure a system of secrecy regarding all affairs of state. ${ }^{7}$

Beyond the confines of the city hall or the Binnenhof there was a lively trade in political information, in part to satisfy the needs of the administrators involved in the political processes of the Dutch state, but also to satiate the curiosity of a literate and inquisitive public. The Dutch Republic was home to the most bookish, educated and literate population of early modern Europe. By the middle of the seventeenth century, literacy rates in the urban centres of the Dutch Republic reached up to $70 \%$ for men and $40 \%$ for women. ${ }^{8}$ The Dutch Republic was the centre of the European book trade, and home to the greatest concentration of booksellers, printers and engravers in the world, catering not only to a large international scholarly audience, but to an enormous domestic market for religious, recreational and political literature. ${ }^{9}$ Many publishers made handsome profits dealing in news pamphlets, political songs, poetry and prints. The widespread availability of political pamphlets not only broadened public political participation, but also normalised the discussion of political issues amongst the broader citizenry. ${ }^{10}$

6 De Bruin, Geheimhouding en verraad. See also Joachim Whaley, Religious Toleration and Social Change in Hamburg, 1529-1819 (Cambridge: Cambridge University Press, 1985), p. 38.

7 De Bruin, Geheimhouding en verraad, p. 15.

8 Willem Frijhoff and Marijke Spies, 165o. Bevochten Eendracht (Den Haag: Sdu, 20oo), p. 237 and Michel Reinders, Printed Pandemonium: Popular Print and Politics in the Netherlands, 1650-72 (Leiden: Brill, 2013), p. 6o.

9 Andrew Pettegree and Arthur der Weduwen, The Bookshop of the World. Making and Trading Books in the Dutch Golden Age (London/New Haven: Yale University Press, 2019); Lotte Hellinga, etc. (eds.), The Bookshop of the World. The role of the Low Countries in the book-trade, 1473-1941 ('t Goy-Houten: Hes \& De Graaf, 2001); C. Berkvens-Stevelinck, etc. (eds.), Le Magasin de l'Univers. The Dutch Republic as the Centre of the European Book Trade (Leiden: Brill, 1992).

10 An argument made effectively also in Jason Peacey, Print and Public Politics in the English Revolution (Cambridge: Cambridge University Press, 2013). 
Although they refused to admit it publicly for fear of blemishing their carefully cultivated reputation, the regents of the Dutch Republic understood that political stability depended on repeated public communication. Implementing the resolutions agreed upon in the Binnenhof required the active consent of the citizens upon whom they were imposed. The regents were obligated to announce their decisions throughout the country, so people were aware of the law, and could assist in its enforcement. This the regents organised through overlapping systems of public communication in the form of solemn proclamations, performed from the balustrade of city halls and from the pulpits of churches, additional announcements made by town criers doing the rounds of a city, and the distribution, generally by affixing, of printed placards." The sheer extent of these communication circuits are only now coming to light, and their reach is often remarkable. More than one hundred different political jurisdictions published printed placards in the seventeenth-century Dutch Republic. Some, like the city of Amsterdam, produced at least two hundred publications a year. ${ }^{12}$ Municipal councils like those of Leiden and Utrecht would hold proclamations every three or four days, in an attempt to demonstrate their authority and regulate the affairs of their citizens with increasing oversight. ${ }^{13}$

In the seventeenth-century Dutch Republic, it was anathema to suggest that politics should involve the people over whom the regents governed. ${ }^{14}$ Yet

11 For some examples see Arthur der Weduwen, "Everyone has hereby been warned." The Structure and Typography of Broadsheet Ordinances and the Communication of Governance in the Early Seventeenth-Century Dutch Republic', in Andrew Pettegree (ed.), Broadsheets: Single-Sheet Publishing in the First Age of Print (Leiden: Brill, 2017), pp. 240-267.

12 Andrew Pettegree and Arthur der Weduwen, 'What was published in the seventeenthcentury Dutch Republic?', Livre. Revue Historique, (2018), pp. 1-22, here pp. 4-7.

13 See for example Het Utrechts Archief, Archief van de Raad (stadsbestuur van Utrecht) 1577-1795, inv. 153-1 and 153-2, and Erfgoed Leiden en Omstreken, Stadsarchief II, inv. 14-22.

14 E.H. Kossmann, Political Thought in the Dutch Republic: Three Studies (Amsterdam: Koninklijke Nederlandse Akademie van Wetenschappen, 20oo), pp. 44, 77, 137, 182; A.Th. van Deursen, Plain Lives in a Golden Age: Popular Culture, Religion and Society in seventeenth-century Holland (Cambridge: Cambridge University Press, 1991), p. 142; Wyger R.E. Velema, Republicans: Essays on Eighteenth-Century Dutch Political Thought (Leiden: Brill, 2007), pp. 35-43. See also G.O. van de Klashorst, H.W. Blom, and E.O.G. Haitsma Mulier, Bibliography of Dutch Seventeenth Century Political Thought: An Annotated Inventory, 1581-1713 (Amsterdam/Maarssen: APA/Holland University Press, 1986). Some contemporary examples are: Simon Stevin, Vita Politica. Het Burgherlick leven (Leiden: Franciscus Raphelengius, 159o), ustC 422851, p. 27 and Marcus Zuerius van Boxhorn, Disquisitiones politicae, of overwegingen van staet en bestiering (Amsterdam: Jan Rieuwertsz and Pieter Arentsz, 1669), pp. 355-356. 
the authorities were deeply concerned about their public reputation. In the absence of a long tradition of hereditary rule, the legitimacy of government, whether it was in Groningen, Amsterdam or Zeeland, rested on the virtues of the regents. ${ }^{15}$ Public perception of government was inextricably tied to its effectiveness. Without the support of a large, permanent police force, rule of law relied on the active cooperation of large groups of citizens. ${ }^{16}$ It was for this reason that the authorities did not limit themselves to their 'regular' systems of public communication. The regents of the States General, the provincial States, and numerous city councils also tried to influence perceptions of their government by indirect means of communication. They influenced the supply of news to raise morale by leaking confidential news reports or missives, often to trusted printers and newspapermen; they organised, in cooperation with the Reformed Church, thanksgiving- and prayer-days to articulate their designs from the pulpit; and they promoted artistic representations of their successes by direct patronage or by distributing rewards to loyal painters, engravers and publishers. ${ }^{17}$

Volatile political times called for more subversive, if not malicious means of communication. In recent years, scholars of the Dutch Republic have paid close attention to the fierce pamphlet wars that engulfed the state in the crisis years of $1617-1618,1650$ and 1672 . In these exceptional years, individual regents often engaged in the publication of anonymous libels, the fabrication or leaking of sensitive political information, and targeted censorship to steer the

15 Jan Hartman, Jaap Nieuwstraten and Michel Reinders (eds.), Public Offices, Personal Demands: Capability in Governance in the Seventeenth-Century Dutch Republic (Newcastleupon-Tyne: Cambridge Scholars, 2009).

16 Henk van Nierop, 'Popular participation in politics in the Dutch Republic', in Peter Blickle (ed.), Resistance, Representation and Community (Oxford: Oxford University Press, 1997), pp. 272-29o.

17 There is not yet a comprehensive overview which treats all of these indirect strategies of communication, but numerous examples can be found in N.C. Kist, Neêrland's Bededagen en Biddagsbrieven (2 vols., Leiden: Luchtmans, 1848-1849); Donald Haks, Vaderland en Vrede: Publiciteit over de Nederlandse Republiek in oorlog (Hilversum: Verloren, 2013); Michiel van Groesen, Amsterdam's Atlantic. Print Culture and the Making of Dutch Brazil (Philadelphia: University of Pennsylvania Press, 2017); Helmer Helmers, 'Onder schyn van trek tot vrede. Politieke spanningen in de Nederlandse vredespubliciteit', in Raymond Kubben (ed.), Ginder 't vreêverbont bezegelt. Essays over de betekenis van de vrede van Breda, 1667 (Breda: Van Kemenade, 2015), pp. 65-77; Helmer Helmers, 'Public diplomacy in Early Modern Europe. Towards a New History of News', Media History, 22 (2016), pp. 401-420; Jill Stern, Orangism in the Dutch Republic in Word and Image, 1650-75 (Manchester: Manchester University Press, 2010). See also Pettegree and Der Weduwen, The Bookshop of the World, pp. 226-228, 244-247. 
outpouring of vitriolic pamphlets towards their opponents. ${ }^{18}$ Perhaps the most famous example of such pamphleteering took place in 1650, when Stadhouder William II attempted to blacken his opponents in the States of Holland over a conflict concerning the size of the Dutch army. Already in December 1649, William had confided in his cousin William Frederick, the Stadhouder of Friesland, that he would have his advisors 'make pamphlets and pasquilles against those who endanger the country and seek to return it to Spain, which will excite and stir the public'.19 During the summer of 165 o, several confidants of William were responsible for handing out subversive texts to printers in The Hague, most notably the brothers Willem and Johannes Breeckevelt. The most virulent publication they produced presented the articles of a fictitious alliance between Amsterdam and the English Commonwealth, signed 'in secret conferences' in London. ${ }^{20}$ According to this tract, the Commonwealth promised Amsterdam 10,00o soldiers and twenty-five warships to subjugate its opponents in the Dutch Republic and depose William as Stadhouder, whose father-in-law, King Charles I, had been executed by the Commonwealth the year before.

When William II had his advisors 'make pamphlets and pasquilles' against his opponents in 165o, he did so under the guise of anonymity. It is only thanks to archival evidence, and the interrogation under torture of the printer Willem Breeckevelt, that we know of William's involvement with pamphleteering in 165o. But the authorities of the Dutch Republic were also capable of criticising one another publicly without any surreptitious means. It was, in fact, more common for the regents to attack their domestic rivals through the publication of official placards and resolutions than to engage in anonymous

18 Reinders, Printed Pandemonium, especially pp. 132, 141-147; Roeland Harms, Pamfletten en publieke opinie: Massamedia in de zeventiende eeuw (Amsterdam: Amsterdam University Press, 2011), especially pp. 81-83, 101-105, 147-155; Femke Deen, David Onnekink and Michel Reinders (eds.), Pamphlets and Politics in the Dutch Republic (Leiden: Brill, 2011).

19 Simon Groenveld, "Een enckel valsch ende lasterlijck verdichtsel." Een derde actie van Prins Willem II in juli 1650', in Simon Groenveld, M.E.H.N. Mout and I. Schöffer (eds.), Bestuurders en geleerden (Amsterdam: De Bataafsche Leeuw, 1985), pp. 113-125, here p. 113 .

20 Articulen, gesloten, ende geaccordeert, tusschen de republique van Engelandt ende de stadt Amsterdam (S.l.: s.n. [=Den Haag: Willem Breeckevelt], 1650), USTC 103116o. See also USTC 1505286, 1505292 and 1516461. See Groenveld, "Een enckel valsch ende lasterlijck verdichtsel", as well as Marika Keblusek, Boeken in de hofstad. Haagse boekcultuur in de Gouden Eeuw (Hilversum: Verloren, 1997), pp. 130-132; Olga van Marion, 'Verboden in de Gouden Eeuw. Schrijvers, drukkers en hun strategieën', in Marita Mathijsen (ed.), Boeken onder druk. Censuur en pers-onvrijheid in Nederland sinds de boekdrukkunst (Amsterdam: Amsterdam University Press, 2011), pp. 31-44, here pp. 32-33, 36, and Harms, Pamfletten en publieke opinie, pp. 101-105. 
pamphleteering. Although this is a strategy of communication that has never been studied as a specific phenomenon, examples are plentiful. During the Remonstrant crisis of the 1610 , the magistrates of several Contra-Remonstrant towns published in print their objections to the unorthodox course of action taken by the States of Holland, embarrassing their fellow regents. ${ }^{21}$ In 1600 , Frisian magistrates from two rural districts set up their own rival States assembly in Franeker after disagreements on new taxation measures. To support their position, they published numerous declarations against their opponents in Leeuwarden over the next two years. ${ }^{22}$ In 1668 , the magistrates of Zierikzee publicly denounced their opponents in the States of Zeeland for recruiting additional companies of soldiers despite the disagreement of Zierikzee and Goes, two members of the States. This they did also by publishing printed resolutions and letters. ${ }^{23}$

One of the worst outbreaks of domestic political discord took hold of Overijssel in the middle of the 165 os. During this period the States of Overijssel was split on the issue of the appointment of a new bailiff of Twente, a large rural district in the east of the province. ${ }^{24}$ One of the factions was led by the towns of Kampen and Zwolle, the other by Deventer; both factions claimed to represent the authentic provincial States, and accused the other of sowing discord. Over several years the factions printed numerous open letters and counter-resolutions to justify their conduct and denounce the 'bitter, calumnious and stinking' declarations of their opponents. ${ }^{25}$ The declarations were

21 Verclaringe vande heeren burgermeesteren van Amstelredam, Enckhuysen, Edam, e⿳亠二口 Purmereynde, Waer by hare E.E. verthoonen hoe verre d'authoriteyt van een christelijcke hooge overicheyt geexerceert behoort te werden (Amsterdam: Marten Jansz Brandt, 1618), USTC 1007138.

22 Lodewijk Mulder (ed.), Journaal van Anthonis Duyck, Advokaat-Fiscaal van den Raad van State (1591-1602) (2 vols., Den Haag/Arnhem: Martinus Nijhoff \& D.A. Thieme, 1862-1864), pp. 589-59o, 716-717. Alzoo eenen yderen bekent is dat die ghedeputeerde van Oostergoe ende Westergoe ([Franeker: Gillis van den Rade], 16oo), USTC 427245, and Oversettinghe vanden recusatie der Hove ofte Rade Provinciael van weghen den Ghedeputeerde Staten van Oostergoe ende Westergoe overghesonden ([Franeker: Gillis van den Rade], 16oo), USTC 427246.

23 Gravamina, ofte 17 pointen van bezwaernis, by de heeren regeerders der stadt Ziericzee; tegens de heeren Staten van Zeelant gemoveert, op den 24. november 1668 (Rotterdam: Johannis Redelijckhuysen [=S.l.: s.n.], 1669).

24 Herbert H. Rowen, John de Witt, Statesman of the True Freedom (Cambridge: Cambridge University Press, 1986), pp. 74-75.

25 Historisch Centrum Overijssel, Stadsbestuur Zwolle, inv. 4967; Staten van Overijssel, inv. $696,1485^{-1486}$. This conflict is now covered in great depth by Jan Haverkate in his recent $\mathrm{PhD}$ thesis, defended at the Free University of Amsterdam, entitled Spindoctors van de Gouden Eeuw. De eerste pamfletoorlog van Overijssel (1654-1675). 
published with full legal paraphernalia, as each side claimed to represent the true States of Overijssel. This paper war culminated in bloodshed in 1657, when troops financed by the Kampen-Zwolle faction besieged Hasselt, a town that had allied itself with Deventer to spite its neighbour Zwolle and accrue greater political recognition in the province. After a short but intense bombardment Hasselt surrendered, news having arrived that a relieving force from Deventer had been scattered by their opponents.

The publicity strategies employed by Dutch authorities in their domestic quarrels with their opponents were realised through established channels of political communication. Legally registered ordinances, formal proclamations and printed placards were essential facets of the daily communication practices of the state. This openness, so far from the dignified aristocratic secrecy of the regents, was a prominent feature of political conflict in the Dutch Republic, and especially in Groningen, during the period of the Ommelander Troubles. The two competing authorities there required their public - at home in Groningen and throughout the country - to rally behind their cause. Lampoons and satirical libels may produce a chuckle or a laugh, but for real political support the authorities of Groningen had to inform and persuade their citizens in the best way they knew how. Far from shutting out their citizens, the magistrates of the city and the Ommelanders employed the engagement of the public as their most potent political tool.

\section{A Province Divided}

The geopolitical characteristics of Groningen were unlike those of any other province in the Dutch Republic. It was known to most metropolitan Hollanders at this time as a strange, distant and stubborn place; the province was, in many ways, characterised by 'cultural isolation'. ${ }^{26}$ It was furthest removed from the urbanised heart of Holland, Zeeland and Utrecht. Its eastern and southern borders (connecting Groningen with East Frisia and the Dutch province of Drenthe) were composed of marshlands; in the west the province shared a narrow passable land border with Friesland. Although a maritime province, Groningen did not possess a seat of the Dutch Admiralty, and played a minor role in the rich shipping trade of the Dutch Republic. Groningen was one of

26 Jan van den Broek, Groningen, een stad apart. Over het verleden van een eigenzinnige stad (1000-1600) (Assen: Van Gorcum, 2007); A. Th. van Deursen, 'Cultuur in het isolement: Groningen', in his Hartslag van het Leven. Studies over de Republiek der Verenigde Nederlanden (Amsterdam: Bert Bakker, 1996), pp. 153-180. 
the least urbanised provinces of the country: its single eponymous city, located at the heart of the province, housed around 20,000 inhabitants. ${ }^{27}$ It towered above the surrounding villages and boroughs that made up the rest of the province; but unlike in Holland or Zeeland, the urban community did not dominate a voiceless countryside. The politics of the States of Groningen was balanced between the city of Groningen on one side, and the three surrounding rural districts of the Ommelanden (Hunsingo, Fivelingo and Westerkwartier) on the other. The Council of Ommelanden was composed of representatives of the landholders of the three districts: the jonkeren (low nobility), hoofdelingen (chieftains), eigenerfden (landowners) and volmachten (representatives of multiple small landowners). ${ }^{28}$ Although the delegates of the Ommelanden sent to represent the Council at the States were predominantly from the jonker class, anyone with at least twelve hectares of land could present themselves at the Ommelanden assembly, the Landdag, and cast their vote. In contrast to the city of Groningen, ruled by a traditional oligarchic council, the Ommelanden Landdag could be influenced by hundreds.

Coming together at the States of Groningen, the Ommelanden and the city both had one vote on all matters of provincial government. But the priorities of the two parties were divergent in many economic and political affairs. Matters of taxation, tolls, fishing and hunting rights, as well as other financial privileges, were hotly disputed by the two sides. To the irritation of the Ommelanders, the city of Groningen took immense pride in its history as a Free Imperial city of the Holy Roman Empire; the more radical Groningers even claimed absolute sovereignty over the entire province, calling their rivals the 'Ommelanden of Groningen'. In defiance, the Ommelanders entitled themselves the 'Ommelanden between Ems and Lauwers' (the two rivers delineating their territory).$^{29}$ Most contentious was the stapelrecht, the right by which the city claimed tax on all goods passing through the province. Imposed since the late fifteenth century, the staple right was maintained with the enthusiastic support of the merchants and guilds of the city. Given the marshy landscape of the province of Groningen, the begrudging Ommelanders had little choice but to pay the Groningers their dues, or else export their goods via the North Sea.

27 Meindert Schroor, Rurale metropool: bevolking, migratie en financiën van de stad Groningen ten tijde van de Republiek (1595-1795) (Groningen: Nederlands Agronomisch Historisch Instituut, 2014).

28 Meindert Schroor, 'Interne staatkundige verhoudingen in Stad en Lande', in M.G.J. Duijvendak, etc. (eds.), Geschiedenis van Groningen II: Nieuwe Tijd (Zwolle: Waanders, 2008), pp. 211-229, here pp. 218-220.

29 Van den Broek, Groningen, een stad apart, p. 99. 
The struggle was complicated by the encroachment of the magistrates of Groningen into the countryside. The bourgeois elite of the city bought up estates in the country, acquired landed titles, invested in the drainage of marshlands, and subsequently raised dues and tolls from reclaimed territories. ${ }^{30}$ The city of Groningen exercised jurisdiction over vast swathes of land beyond their walls: the districts of the Oldambt, Gorecht and Westerwolde (located to the south and east of the city) all fell under the rule of the city (see figure 7.2). The city, in effect, governed half the Groningen countryside. But this infiltration could go both ways. Most jonkers owned properties in the city of Groningen: while the Ommelander aristocracy took great pride in their country manors (borgen), many were wealthy individuals, some worth as much as 100,00o gulden, and they retained a substantial urban presence. ${ }^{31}$ The city provided a means to spend and be seen. Furthermore, because the city was situated at the centre of the province, the Council of Ommelanden maintained their official assembly (the Ommelander House) on the Schoolstraat in Groningen, a minute's walk from the city hall (see figure 7.3). While the Ommelanders sometimes convened outside Groningen - in the small towns of Aduard, Appingedam or Winsum - they could generally be found at the heart of opposition territory. The magistrates of Groningen frequently disrupted the Ommelander Landdag in the city. In 1676 they would go as far as to arrest a leading Ommelander jonker, Osebrant Jan Rengers van Slochteren, as he came out of a States of Groningen meeting in the city, accusing him of treason. This intervention would spark yet another outburst of violence across the province.

Groningen was an isolated province, but it did boast a sophisticated internal infrastructure. By the end of the seventeenth century, Groningen had a network of canal barges to rival that of Holland, with a major route stretching across the province from west to east, and numerous offshoots flowing north, connecting many peripheral towns to central Groningen..$^{32}$ The ease with which citizens in Groningen could travel through the province, and the inevitable encounters between rival city burghers and Ommelanders would only increase tension between the two camps.

30 Hidde Feenstra, Spinnen in het web. Groningse regenten in relatie tot het omringende platteland tijdens de republiek (Assen: Van Gorcum, 2007).

31 Johan de Haan, 'Ommelander jonkers', in IJnte Botke, etc. (eds.), Het grote geschiedenisboek van de Ommelanden (Zwolle:Waanders, 2011), pp. 54-75; W.J. Formsma, R.A. LuitjensDijkveld Stol and A. Pathuis, De Ommelander borgen en steenhuizen (Assen: Van Gorcum, 1973), pp. 30-35; Hidde Feenstra, De bloeitijd en het verval van de Ommelander adel (1600180o) (University of Groningen, PhD dissertation, 1981).

32 Jan de Vries, Barges and Capitalism: Passenger transportation in the Dutch Economy (16321839) (Utrecht: H\&S, 1981), pp. 30-35. 


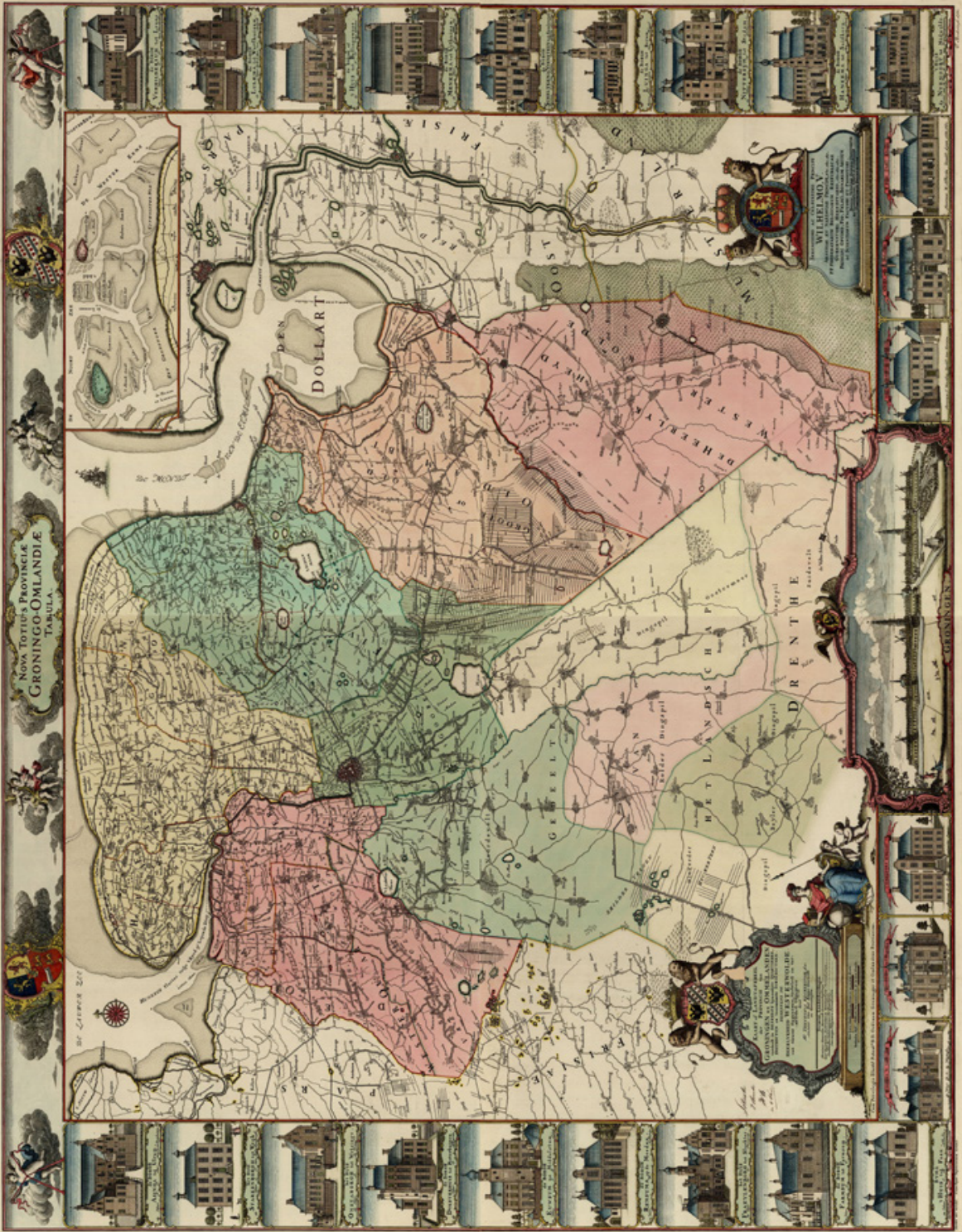

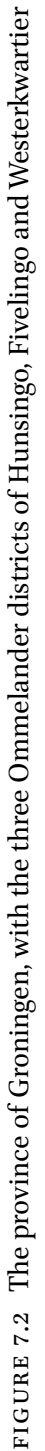



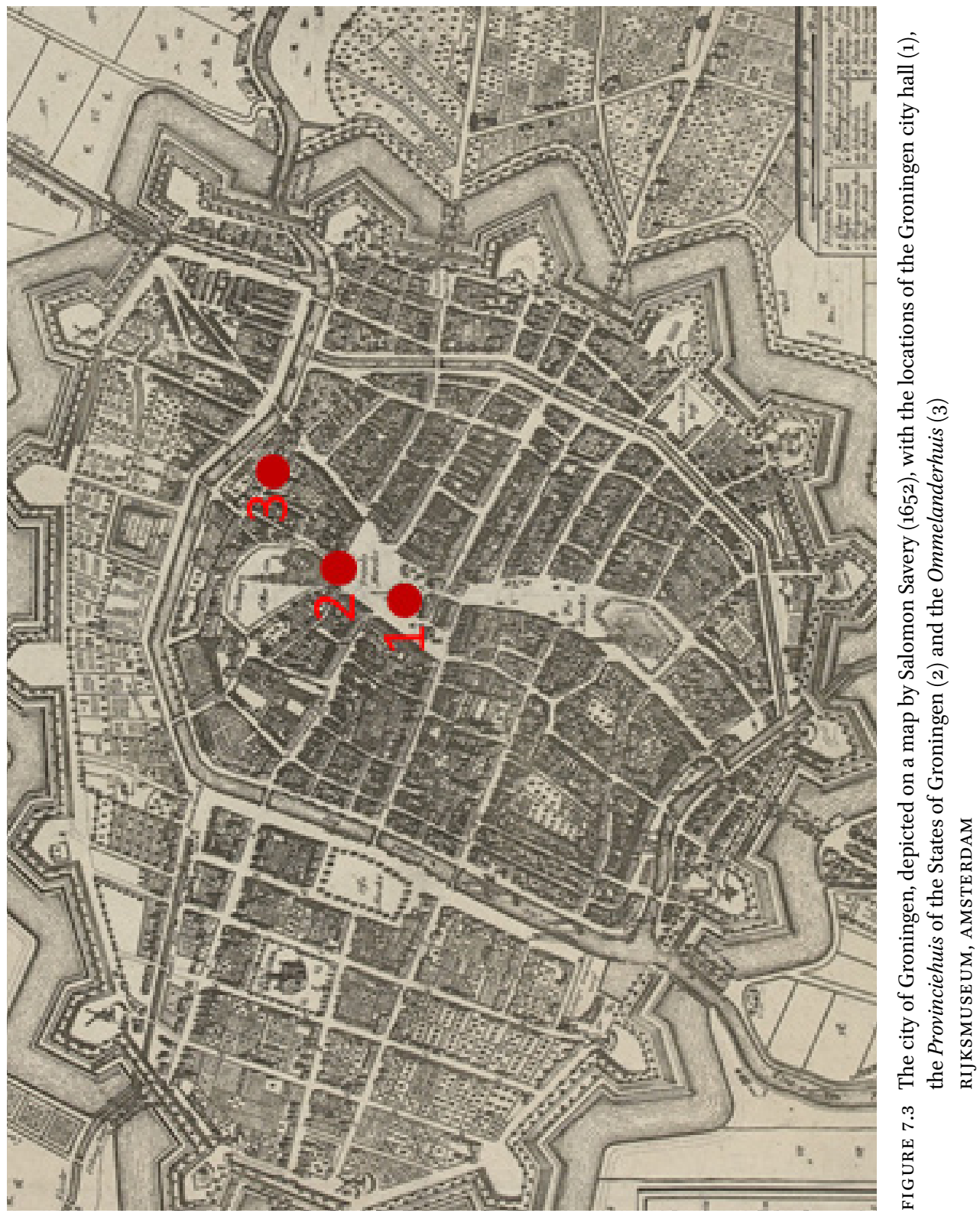


\section{Troublesome History and a Turbulent Conflict}

How did this peculiar political settlement come to be? For much of the seventeenth century, the Ommelanders did not even wish to share their provincial government with the urban Groningers. Their grievances stemmed from the fifteenth and the sixteenth centuries, when the city expanded aggressively into the countryside, subjugating most of the surrounding Ommelanden and imposing their hated staple right. The city observed closely the divisions within the Ommelanden, exploiting the differences between the nobility and landowners. The tables turned when the Ommelanders declared themselves for the Dutch Revolt against Habsburg authority, while the city, under the leadership of Stadhouder Count Rennenberg, declared for the King. Groningen remained under Habsburg control until 1594, when the city was taken by the forces of the States General. The gleeful Ommelanders, instrumental in the siege of the city, hoped for significant concessions and a diminution of the commercial privileges of the city; they advocated for a separate province, with Groningen itself to be ruled as a military enclave by the States General.

The proud Ommelanders were to be disappointed. The States General wished to maintain a bulwark against Habsburg aggression in the north, and required the powerful city and its defences to do so. The terms of the 1594 reduction were extremely lenient: all past injuries were to be forgotten (article 1), and the city was 'to be and remain undiminished in its privileges, liberties, customs and freedoms' (article 3). ${ }^{33}$ The terms also formulated the constitution of the States of Groningen, establishing the equality between the city and the Ommelanders. Because of its function as a constitutional charter, the terms of the reduction became a rallying point for any future conflict in the province. As far as we know, the text was reprinted in Groningen in three different editions in 1646 , and again in 166 o and $1678 .{ }^{34}$

The terms of reduction were frequently contested, as were many other economic privileges, including toll rates and fishing rights. ${ }^{35}$ Aside from the

33 Articulen ende conditien vant verdrach gesloten by Graef Wilhelm van Nassau uyt naeme der heeren Staten Generael der vereenichde Nederlanden: mette stadt Groeninghen ende tgarnisoen opt overgeven vander selver stadt (Den Haag: Aelbrecht Hendricksz, 1594), USTC 415489, f. A2.

34 See for example Poincten ende conditien gemaeckt tusschen zijne Excellentie den here Prince Mauritz van Orangien ende de Stadt Groeningen ter andere sijden (Groningen: weduwe Edzard Huysman, 166o).

35 See especially the numerous cases covered in GAG, Ommelander Archieven, inv. 758-888. Also Meindert Schroor, 'Heroriëntatie op de unie en op Holland', in M.G.J. Duijvendak, etc. (eds.), Geschiedenis van Groningen II, pp. 152-209, here pp. 159-161. 
welcome additional income that these privileges brought in, these claims became battlegrounds because they represented a struggle for authority, fought on the part of the Ommelanders for greater autonomy, and by the Groningers for the maintenance of their power over the countryside.

Authority is inextricably tied to public demonstrations of power. With each major outbreak of conflict in Groningen, both sides articulated their claims to authority to a wider public. By the 1640s, printed broadsheets, pamphlets and fliers had come to play a fundamental role in the development of the struggle. The most violent bout of conflict opened on 22 November 1639, when the magistrates of Groningen published an ordinance against jonker Sebo Huninga (see figure 7.4). ${ }^{36}$ Huninga was a jonker of the Oldambt, one of the rural territories under the sovereignty of the city. With Huninga's urging, the Oldambt declared itself independent, and elected representatives to attend the Ommelander Landdag in Appingedam. The magistrates despatched the printed sentence condemning and banishing Huninga across the province, and tried in vain to arrest him in the Oldambt. Huninga fled to Ommelander territory while the landowners of the Oldambt began to arm themselves. Desperate for allies, they appealed to the Ommelanders for assistance. On 11 December, the Council of Ommelanden published a broadsheet that declared that Huninga was under their protection; they also announced that they considered the Oldambt a land of 'free people', whom they would gladly incorporate into Ommelander territory (see figure $7 \cdot 5){ }^{37}$

This public provocation established a norm of political communication that would dominate the conflict in Groningen for the remainder of the seventeenth century. Every sentence, declaration or ordinance published by one of the authorities would be followed by a response from their opponent. It was imperative that the rival authorities of Groningen responded to one another in kind. The secretary of Groningen, Bernard Alting, highlighted the importance of proclamations when he claimed that Groninger sovereignty over the Oldambt was proven 'by the fact that for the last hundred years no ordinance,

36 Sententie van borgemeesteren e⿳亠二⿵ raedt in Groningen, tegens Sebo Huninga (Groningen: Hans Sas, [1639]), USTC 1021672. On this episode of the conflict see Meindert Schroor, 'Ontwrichting en oligarchisering: het midden van de zeventiende eeuw', in M.G.J. Duijvendak, et. al. (eds.), Geschiedenis van Groningen II, pp. 230-243, here pp. 231-235 and Marjolein 't Hart, 'Rules and Repertories: The Revolt of a Farmer's Republic in the Early Modern Netherlands', in Michael P. Hanagan, Leslie Page Moch and Wayne te Brake (eds.), Challenging Authority: The Historical Study of Contentious Politics (Minneapolis, MN: University of Minnesota Press, 1998), pp. 197-212.

37 De Heeren Gecommitteerde Raden der Omlanden doen te weten: alsoo ons is geremonstreert hoe dat borgemeesteren den E.E. Sebo Huninga deden vervolgen; soo ist, dat wy protesteren, nemende de selve Huninga in onse protectie ([Groningen: s.n., 1639]), USTC 1122316. 


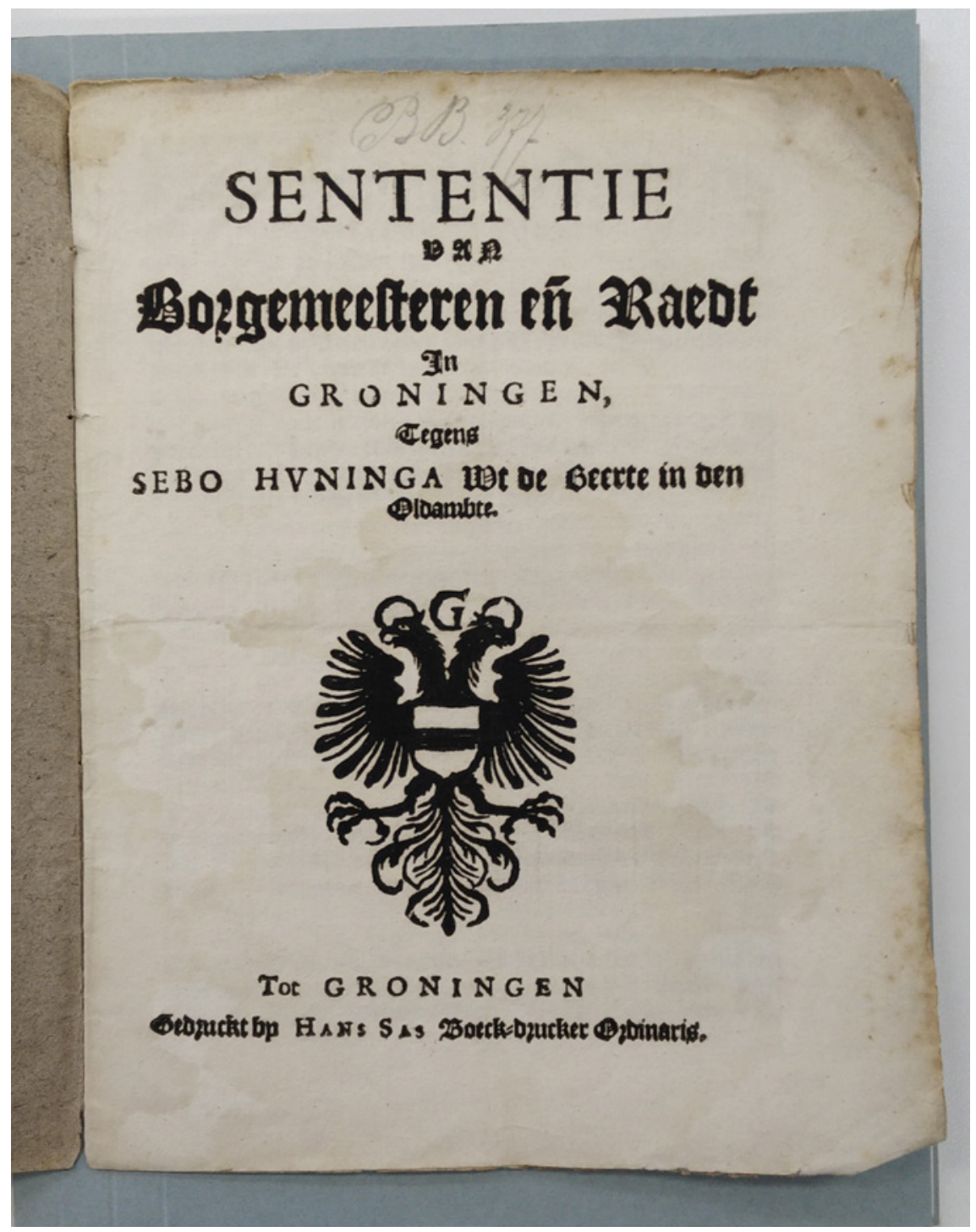

FIGURE 7.4 The magistrates unleashed the worst round of conflict with their condemnation of Sebo Huninga in 1639 UNIVERSITEITSBIBLIOTHEEK, GRONINGEN 


\section{DeHeeren Gecommitteerde} Raden der Omlanden, tuffchen d'Eems ende Lauwers, foo Ordinaris als Extra-ordinaris, in defen expreffe gelaftet : D O E T E W E T E N :

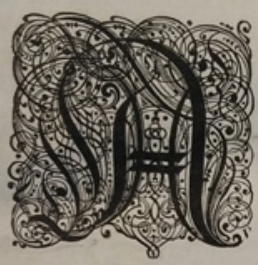

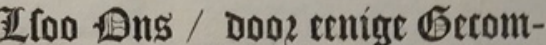

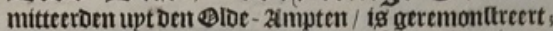
Goe bat Bosgemeefteren enoe kacot ber sotabt Groeningen/

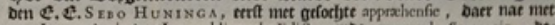
openbarte enoe in oputk gepublicecrde Ldicten embe remeynde Sententie, be Den verbolgen; ter caufe bau tenight fiemonftrantien / be bem/ in qualitepe

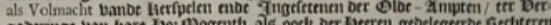

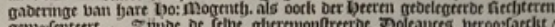

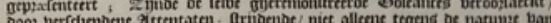

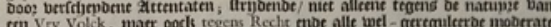

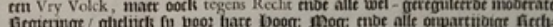

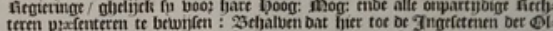

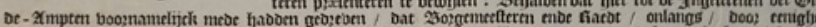

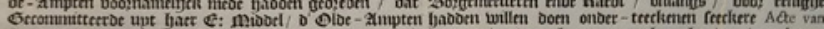

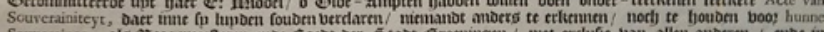
Sowverainen, als 303 gemetferen mDe fiatot oer 5taot Eroeningen / met ertufie van allen anberen / mbe in

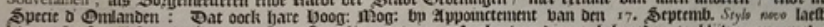

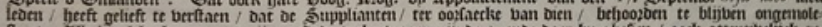

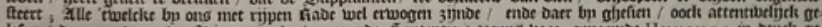

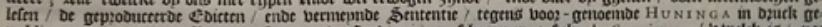

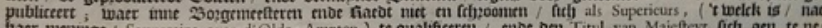

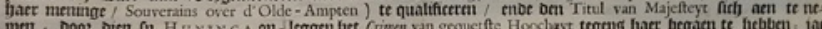

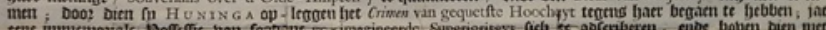

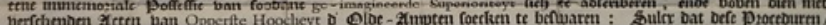

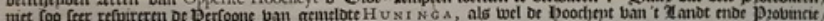

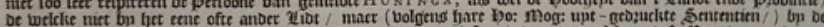

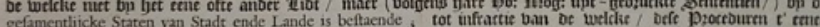

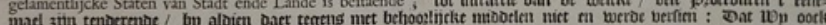

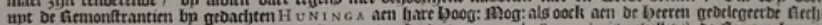

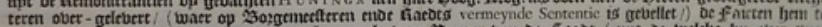

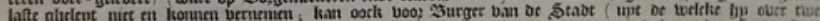

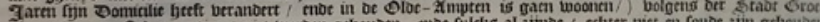

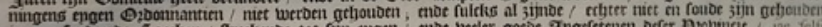

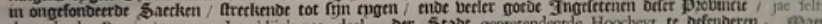

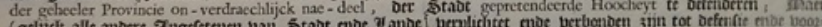

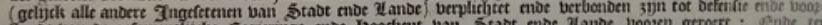

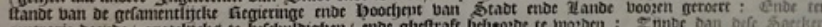

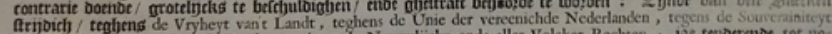

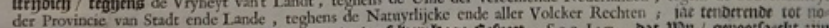
der Provincie van Stade ende Lande, teghens de Natuyrijcke ende aller

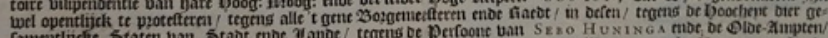

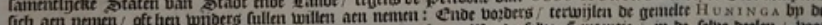

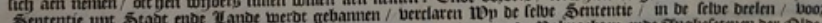

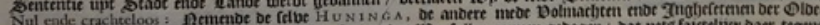

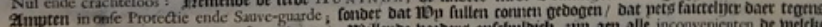

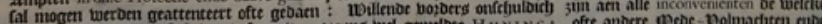

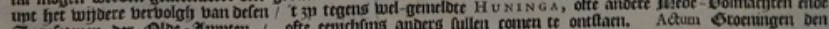
Tingeiternen ote Oloc-2tmpten /

$$
\text { O. T A M M I N A, with }
$$

Ter Ordonnantic der Heeren voorfchreven.

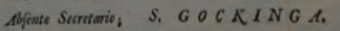

FIGURE 7.5 The Ommelanders immediately came to Huninga's rescue, and took up the fight for a free Oldampt in a series of placards like this one, published on 11 December 1639

GRONINGER ARCHIEVEN, GRONINGEN 
constitution, law, edict, decree or placard has been issued and published in the Oldambt except for those by the city of Groningen'. ${ }^{38}$ As soon as one of the parties staked their claim in a public space, their opponent was required to issue a response or else relinquish their political authority.

Usually ordinances were published and affixed only in the jurisdiction where the respective authority exercised their right, but these back-and-forths ignored all legal boundaries between the Groningers and the Ommelanders. Both sides appealed to their own citizens and those of their opponents: messengers from the city proclaimed ordinances outside the city's jurisdiction, while their Ommelander colleagues affixed broadsheets across the Oldambt and the Groninger cityscape. ${ }^{39}$ A Groninger placard of 5 January 1643, prohibiting the implementation of an extraordinary tax issued by the Ommelanden on 9 December 1642, was directed firstly to all subjects of the Ommelanden, and secondly to all citizens of Groningen. Invariably, these cross-jurisdictional proclamations were rapidly denounced by the opposite side. On 26 August 1646, the Council of Ommelanden issued an ordinance against a Groninger placard of 8 August, and urged Ommelander officers to prosecute all individuals who 'distribute, affix or try to affix' the Groninger placard as 'disturbers of the common peace and defilers of the Ommelander freedoms and rights'. The officers were then to destroy the broadsheets. ${ }^{40}$ On other occasions, the magistrates of Groningen retaliated in similar fashion, burning in public a contested Ommelander placard. ${ }^{41}$

Pasted up, distributed and read out all around the province, the competing broadsheets presented the authorities with the means to attract attention to their cause and justify their policies. The citizens of Groningen received illuminating insights into the nominally secretive political debates between the two authorities. On 18 August 1647, the Ommelanders published a lengthy two-sheet placard, entitled The origins and present state of the provincial unrest, portraying: 1. The injustice of the magistrates of Groningen, with which they mislead their own citizens, and insult the country. 2. What serpent lies under the magistrates'

38 Bernard Alting, Der Old-ambten dependentie, van de stadt Groningen (Groningen: Hans Sas, 1643), USTC 1026102, p. 43.

39 See for example Placcaet van borgemesteren ende raadt in Groningen tegens twee onbevougde placcaten van den Ommelanden (Groningen: Hans Sas, [1646]) and Borgemesteren ende raedt in Groningen: alsoo eenige weynige jonckeren, buyten onse kennis te doen affigeren seecker placcaet ([Groningen: s.n., 1651]).

40 De Heeren raaden der Ommelanden soo ordinaris als Extraordinaris gecommiteert. Gesien hebbende een placcaet by borgemeesteren der stadt Groeningen den 8. Lopendes maents Augusti geemaneert ([Groningen: s.n., 1646]), USTC 153208o.

Op het verbranden van het nieuwe Omlander reglement (Groningen: Jan Collen, 1671). 


\section{E HEER E N R A 1 D E N}

der Ommelanden foo ordinaris als extraordinar Gecommiteert.

\section{Gefien bebbende een 引Jlatcate b. Borgemeefferen

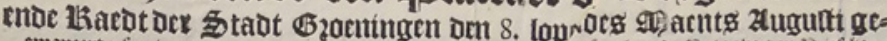

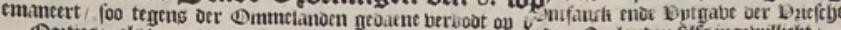

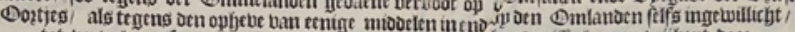

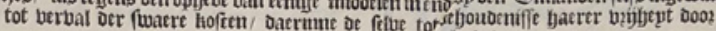$$
\text { oer oer Śtaotos heònf fò getęuot. }
$$$$
\text { Doen daer tegen te weeten. }
$$

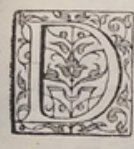

\section{At Borgemeeffect ende Rated hebbende gedaen op De felbe Botteng/ particuliere berbodt inde Stadt/}

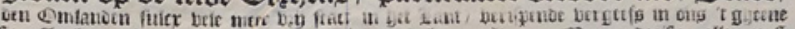

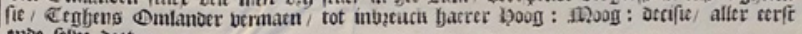
thoe felve Doct.

Wet berbal ofte fuypozt by ons felf, uut onfe eygen goede, niet tot lafte ban tenigh Tngeften ban oe Staot: nitt ractienoc oe oude toe cerlienoe 6400 , ne oe Staot ong etrine jaren iongft, tot befcherminge vander Omlander vryheyt ende recht hetft melvotrt. Sul

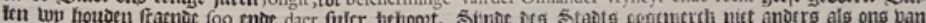

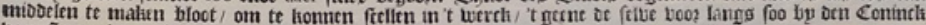
bau Spangien / als by oefen Statt ooos te oringben beeft fitenteert: Nantentligh ten ceuwige Servituyt

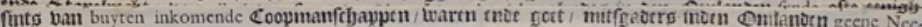
ringe, Ambachten, Ampten ofte exercitic te mogen doen : 'tfin of tygene woozern oie oe Stabt beeft ghe butucht.

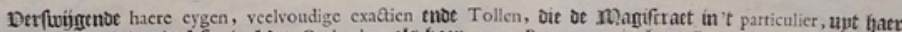
eyeen hoof, tot naberl foo wel oer Omlanden als facr eygen Borgerye, in batr Pont ofte Tolkamers linfe

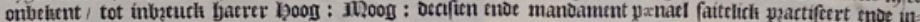
Dมุingt.

SO IST Dat oe veeren Der Omlanoen berblijuen bp hare boosigbe helientmaechingen enoe placeact on

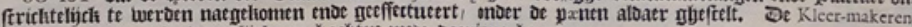
Stecn-meticlaers ende Duergeliyclie ambachten meve Daerinne begrepen.

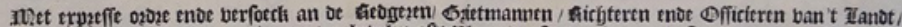
om alle oie netne oe belchie ecnige contra bebelen ofte glaccaten fouoen liomen te fropen/ atn te faen / ofte onoerfaen an te farn/ te achterhalen: ende tegeng oe eloe te proctoeren als perturbateurs der gemeene ruf

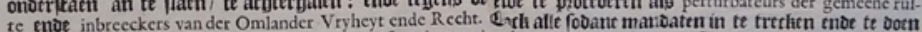

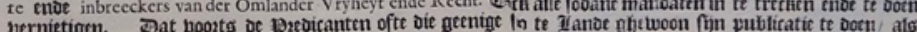

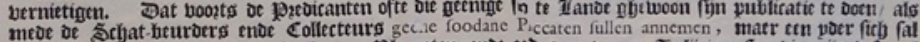
fehben te regulieren nae oer Dmlanoen placeaten enoe $020 ;$ ban oen 3 . Tuly fongft / oie mitg oefen al noch weroen baft nefelt enoe neconfirmetrt / Enllenoe afle the etn poer in't naertiomen ban oefen ban't

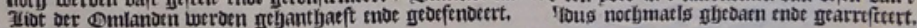
Defen 26. Flugufin 1646 .

O. I. Rsughers cot Slochteren ve.

eer ogoonantic oer Deeren boozf;

$$
\text { A: Berchuys Secret: }
$$

FIGURE 7.6 Responding in kind: the Council of Ommelanden condemn a Groninger placard of 8 August 1646

GRONINGER ARCHIEVEN, GRONINGEN 
efforts, in which they revealed in some detail the arguments advanced in the meetings of the States of Groningen. ${ }^{42}$ The Ommelanders closed with a warning to all citizens of the province that it was the magistrates who had colluded with the King of Spain, and the Ommelanders who had fought for liberty.

The solemn decorum normally associated with the publication of the law was largely abandoned in the chaos of the Groningen conflict. Instead the public was exposed to the internal divisions of their regents and the relentless struggles for dominance between different factions. On 26 February 1657 , the Council of Ommelanden published a placard against the magistrates of Groningen, denouncing their opponents and accusing them of disrupting the assembly of the States of Groningen. ${ }^{43}$ This was followed two weeks later by another Ommelander broadsheet, which claimed that the last placard was produced by 'restless people' who did not have the authority to speak on their behalf.44 This public misstep by the divided Ommelanders was eagerly exploited by the magistrates: on 17 March they issued an ordinance in which they announced that

we have received two different placards or manifests issued by the Council of the Ommelanden dated 26 February and 14 March ... which demonstrate the notorious divisions and dissent in the Ommelanden ... and so we have been forced to note in the register of provincial resolution that it is impossible to deliberate with the Ommelanders when they are so divided and disunited.... ${ }^{45}$

The repeated cycle of conflict in Groningen reverberated throughout the Dutch Republic. An important clause in the terms of reduction of 1594 was that all future differences between the Ommelanden and the city were to be resolved 'through determination and judgement of the gentlemen of the States General, or their commissaries' (article five). Public opinion in The Hague was therefore crucial to the success of the Ommelander or Groninger cause, and

42 Oorsaecke ende toestant onser provintie on-ruste (S.I.: s.n., [1647]), USTC 1036013.

43 De heeren van den Ommelanden tusschen d'Eems ende Lauwers doen te wieten: alsoo wy met groot leedtwesen moeten aensien, dat de provinciale regieringe van justitie ende politie is onbestelt gebleven tot schaede ende ondienst der provincie ([Groningen: s.n., 1657]).

$D[$ sic] Heeren van de Ommelanden tusschen den Eems ende Lauwers. Doen te wieten. Also ons is ter handt gekomen seker seditieus placcaet by die name van het corpus der Ommelanden uytgegeven ([Groningen: s.n., 1657]).

45 Borgemeesteren ende raedt in Groningen doen te wieten. Alsoo ons zijn ter hant gekomen twee verschillende placcaten ofte manifesten, by d'heeren van d'Ommelanden geemaneert ([Groningen: s.n., 1657]). 
both parties endeavoured to rally supporters to their banner. Both sides sent frequent delegations to the States General, but also to their neighbours at the States of Friesland, or to the Stadhouder, urging them to declare their position. In the later 163os, the magistrates of Groningen maintained a permanent agent in The Hague, Willem van der Gracht, who was paid a pension of 200 gulden a year to represent his paymasters and report back on the mood in The Hague. ${ }^{46}$

Agents like Van der Gracht were crucial to the lobbying process in The Hague. The delegates from the city of Groningen and the Ommelanden formally submitted supplications to the meetings of the States General, presenting their cause verbally before providing copies of their propositions for discussion. ${ }^{47}$ But to bring the urgency of their petitions to attention, agents and delegates could press their missives and pamphlets into the hands of regents on the Binnenhof. On missions beyond their own province, the Groningers and Ommelanders sustained their publicity campaign: their ordinances and remonstrances were often reprinted in The Hague. In November 1677, the Ommelanders paid an unspecified sum to Roeland van Kinschot, a councillor of the High Court of Holland, for the publication of declarations and tracts. ${ }^{48}$ Such reprints were generally broadsheet or pamphlet ordinances, copied faithfully from the originals printed in Groningen. ${ }^{49}$ Shorter pieces were reinforced by lengthy justifications: in 1640 Sebo Huninga's Bewys vande vryheyt ende independentie der vrije Oldampten (Evidence of the liberty and independence of the free Oldampt), a 150-page tract, was published in Rotterdam. The publications were initially distributed for free; others made their way into the hands of booksellers in Amsterdam, The Hague and Utrecht. Publishers like Hendrick Laurensz and Johannes Verhoeve stocked ordinances and pamphlets published by both sides of the conflict, as well as the interventions of the States General. ${ }^{50}$

$46 \quad$ GAG, Archief van de stad, inv. 332, f. 388v.

47 See for example Verscheyden resolutien van de Heeren Staten Generael der Vereenigde Nederlanden of $165^{2}$ (S.I.: s.n., 1652): 'on Wednesday 8 May 1652, there was presented and read at the assembly of the States General the written proposition of the gentlemen commissaries of the Ommelanden ...'

48 GAG, Ommelander Archieven, inv. 411, f. 22v.

49 An example is Die Heeren van den Omlanden, doen te weten: Alsoo het door hem selve is bekendt, dat het recht van tollen die souverainiteyt, dat is d'eenparige provinciale hoogheyt en [de] regeringe van Stadt ende Landt toekomt (Den Haag: Isaac Burchoorn, 1642), USTC 1122317 .

50 Catalogus variorum \& insignium librorum Hendrici Laurentii P.M. bibliopolee Amsterodamensis ([Amsterdam]: erfgenamen Hendrick Laurensz, [1649]), USTC 1022549; Catalogus variorum, insigniorum librorum officinae Johannis à Waesberge (Utrecht: Johannes Janssonius van Waesberge, 16o9 [=166o]); Catalogus variorum insignium librorum 
All too often the conflict placed the regents of Holland and the other provinces in a difficult position. Due to the balance between the Ommelanders and the city, it was rarely possible to please both, as the States General had found shortly after the reduction of 1594. Furthermore, the conflict in the north-east of the country provided an ideal means for disgruntled statesmen to fight out altogether different battles. In 1676 and 1677 , when a new bout of warfare broke out, the States of Friesland and the Stadhouder of Friesland and Groningen, Hendrik Casimir II, came to the rescue of the magistrates of Groningen, who had been reprimanded by the States General and Stadhouder William III. The Frisians and Hendrik Casimir had a bone to pick with the States General and William III, and published several letters and resolutions declaring their indignation with their colleagues. Hendrik Casimir also affixed placards across the Ommelanden invalidating the ordinances of the States General. The Ommelanders had the placards ripped down, and printed a furious letter to Hendrik Casimir (their own Stadhouder), accusing him of making the Ommelanders 'slaves' of Groningen, and of deriding the memory of his ancestors. Hendrik Casimir, somewhat shaken by the audacity of the Ommelander letter and its violent imagery, published a response in which he questioned whether it had been produced by a rogue delegate of the Council. With the threat of William III's troops being sent to the province, Hendrik Casimir and the Frisians retreated.

The conflict in Groningen has scarcely been noticed by scholars of the Dutch Republic, but in its time it generated significant national interest. In 1678, a quarter of the content of the Hollandse Mercurius, a hugely popular annual review, was devoted to the conflict between the city of Groningen and the Ommelanders. ${ }^{51}$ The fact that the Hollandse Mercurius usually limited itself largely to international political affairs demonstrates the impact of the struggle on the national media. The literature of the conflict has survived very well, because it was collected by contemporaries. Seventeenth-century auction catalogues reveal several libraries that were stocked with bound volumes of 'political tracts of the city of Groningen and Ommelanden', or other

incompactorum officinae Johannis Verhoeve (Den Haag: Johannes Steucker, 1662); Verzeichnus vieler schönen ungebundenen in Teutsch und Niederländischen Sprache Bucher (Amsterdam: erfgenamen Johannes Janssonius, 1665).

51 De nieuwe Hollantse Mercurius, verhalende van oorlog en vrede 'tgeen in en omtrent de Vereenigde Nederlanden, en by gevolge in geheel Europa, in't jaer 1677 is voorgevallen. Acht-en-twintigste deel (Haarlem: Abraham Casteleyn, 1678), pp. 98-154. 
publications on the struggle. ${ }^{52}$ Some of these bound volumes survive in library collections today. ${ }^{53}$

The terms of the reduction of 1594 ensured that the States General was bound to be involved in the provincial rivalries of Groningen. Yet there was another reason for the national interest in the conflict. The nature of the Dutch union ensured that each of the seven provinces held one vote at the States General concerning all matters pertaining to foreign policy and the national defence budget. When the two authorities of Groningen were at loggerheads (over what must have seemed to the regents in The Hague like trivial rural matters), the other provinces could not rely on Groningen to offer a coherent opinion on federal policy. In a letter of 22 May 1677 , William III of Orange wrote that

It causes us much grief to have seen for the last two years the province of Stad and Lande [Groningen] in such a state, that it can present no help or assistance to the general union, and even obstructs [the union], leaving the contributions to the general means for the maintenance of the army to be carried by the other provinces, to the detriment of the generality ... ${ }^{54}$

William was frustrated because a few nobles in the Ommelanden and the bourgeois peat dealers of Groningen could easily undermine his international political designs. The contest between the Ommelanden and the burgomasters was a constant reminder of the disunity of the state, of the stubbornness of its inhabitants and the unsuccessful efforts of the Stadhouder and the States General to resolve the troubles.

\section{Profitable Strife}

The printers and booksellers of Groningen had no complaints. They secured significant business from the conflict, and they played an important role in

$5^{2}$ Bibliotheca Oizeiliana (Leiden:Jacobus Hackius, 1687), pp. 183-184; Catalogus Bibliothecae Insignis Quam Magno Studio Et Sumptu Sibi Comparavit Praenobilis ac Generosus Vir, Dn. Reinoldus Alberda (Groningen: Cornelis Barlinckhof, 1692), pp. 31-34, 42-43, 50-51; Catalogus Variorum \& Insignium Librorum, Praecipue Juridicorum, Nobilissimi Dom. Guilhelmi Ploos ab Amtsel [sic] (Utrecht: Dirck van Ackersdijck, 1667), f. B2v; Gatalogus [sic], Variorum \& Insignium Librorum, Clarissimi Viri, D. Marci Boeraven (Leiden: Franciscus Hackius, 1645), USTC 1122152, p. [21].

53 See for example Universiteitsbibliotheek, Groningen, vol. Backer 297.

54 Cited in De nieuwe Hollantse Mercurius, p. 130. 
its development. Before the 1640s, only two printers, Hans Sas and Nathanael Roman, had plied their trade in Groningen. ${ }^{55}$ Around 1650, not coincidentally around the height of the Ommelander conflict, there were no fewer than nine print shops in the city. The authorities of Groningen were some of their most important customers. Groningen publishers were some distance removed from the great centres of the international book trade, and rarely took on significant projects that could rival competitors in Amsterdam, Leiden or Frankfurt. Instead, they looked to the professors and students of the local university and the secular authorities for most of their business: more than $80 \%$ of the known output of Groningen printers in the seventeenth century is composed of official or academic print. In years of heightened conflict, such as 1677 , almost every single book published in Groningen concerned the political crisis between the magistrates and the Ommelanden. ${ }^{56}$ The largest portion consisted of broadsheets and pamphlets, delivered directly to the authorities for distribution.

Because the conflict was often a debate concerning privilege and custom, publishers also provided reprints of historic ordinances and compendia of placards on the conflict. ${ }^{57}$ When arguing for the Ommelander cause in 1677 , the secretary of the Council of Ommelanden, Henric Piccardt, cited interventions of the States General of 1599, 166o, 1662, 1663, 1667, 1610, 1615, 1628, 1640, 1645,1649 and 1650.58 A Groninger placard of 5 January 1643 was accompanied by an annotated reprint of the 1599 States General ruling in order to reinforce the argument that the Ommelanders had not fulfilled their financial obligations to the province. The contending parties (and the bewildered regents throughout the rest of the country) had to keep track of the ever-extending narrative of conflict, and their need for reference copies was satisfied by the grateful printers of Groningen.

During the first half of the seventeenth century, Hans Sas was the most important printer-publisher active in the city. He opened a print shop in 1607 ,

Harry van der Laan, Het Groninger Boekbedrijf. Drukkers, uitgevers en boekhandelaren in Groningen tot het eind van de negentiende eeuw (Assen: Van Gorcum, 2005), pp. 33-51.

56 Out of 38 works known to have been printed in Groningen in 1677, 34 concerned the political crisis.

57 Copulaten van remonstrantien, memorien acten, resolutien, missiven, protesten, en andere stucken gedient hebbende in het different tusschen beyde leden van stadt Groningen ende Ommelanden (Groningen: Cornelis Barlinckhof, 1677) and the Verzameling van missiven, copulaten e.d. van de Staten Generaal aan de burgemeester en raad van Groningen, 1677 ([Groningen: s.n., 1677).

Cited in De nieuwe Hollantse Mercurius, p. 127. 


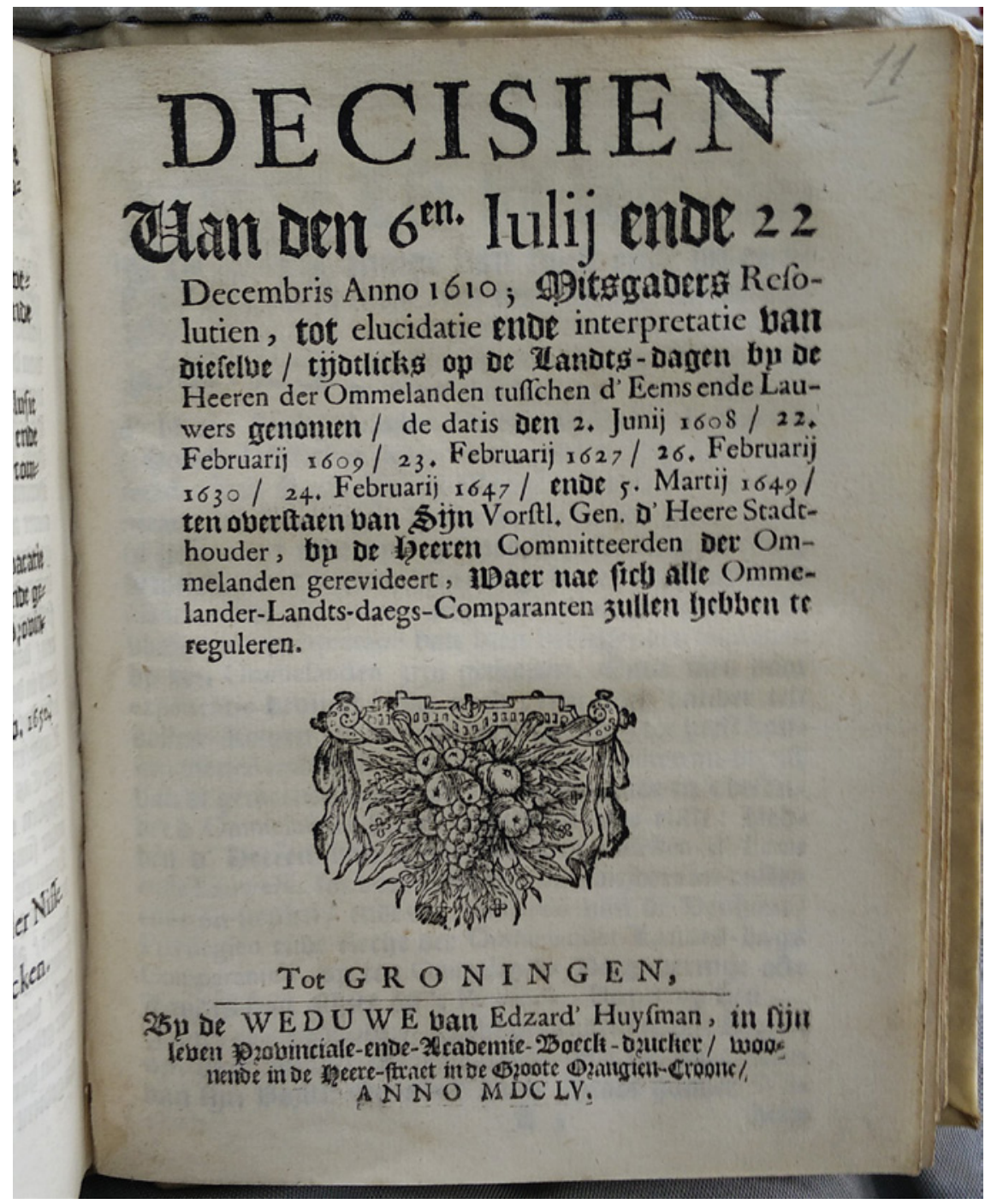

FIGURE 7.7 The printers of Groningen were happy to accommodate the contesting authorities with numerous reprints of historic ordinances and resolutions UNIVERSITEITSBIBLIOTHEEK, GRONINGEN 
and remained in Groningen until his death in 1651 . He was appointed stadsdrukker (printer to the municipality) by the magistrates, Statendrukker (States printer) by the States of Groningen, and he became the first academy printer of the University of Groningen. When he died he was honoured by a funeral service directed by the university. ${ }^{59}$ Until the arrival of Nathanael Roman in 1629, Sas was the only printer in Groningen; clearly a valued and respected member of the community, he was also paid well. The magistrates usually paid him around 1,ooo gulden a year for the delivery of placards, books and stationery. ${ }^{60}$ When the magistrates of Groningen published their first volley of declarations against the Ommelanders in 1639, they naturally turned to Sas for his services.

Until the end of the eighteenth century no printers would establish themselves in the rural Ommelanden. It is therefore all the more remarkable that the Ommelanders were so quick to respond to their opponent's declarations in print. All Ommelander placards, ordinances and resolutions had to be printed right under the noses of the magistrates of Groningen. During the 1640 s it was Hans Sas, the esteemed printer of the town, who also provided the Ommelanders with their ordinances. While he was happy to receive Ommelander cash, it is no surprise that Sas, or any other Groningen printer after him, never placed his imprint on the publications of the Council of Ommelanden. That might have been one provocation too many for the magistrates.

After the death of Hans Sas, the printer Jan Claessen became the new stadsdrukker, while Edzard Huisman received the privilege of Statendrukker and academy printer. The Ommelanders maintained their habit of having their ordinances printed with the Statendrukker. Judging by the sums paid by the Ommelanders, only a fraction of their declarations and ordinances have survived. The Council of Ommelanden paid Edzard Huisman close to 400 gulden in 1651 , and over 1,ooo gulden in 1652. The widow of Edzard Huisman, who took over his positions in 1654 , received no less than 7 , ooo gulden from the Ommelanders between 1659 and $1666 .{ }^{61}$ These were significant payments. While they clearly preferred the Huismans, the Ommelanders did not restrict themselves to their services. On 17 November 1677 , the Ommelanders paid out 1,ooo gulden to 'several printers' for the publication of declarations and tracts. ${ }^{62}$ Other statements in their account books reveal that these 'several printers' included Samuel Pieman, as well as the stadsdrukker Cornelis

\footnotetext{
59 Rector Academiae [funeral oration for Johannes Sas, 29.09.1651] (Groningen: s.n., 1651).

6o GAG, Archief van de stad, inv. 332, f. 397v.

61 GAG, Ommelander Archieven, inv. 397, f. 19r; inv. 398, f. 16v; inv. 399, f. 18r; inv. 401, f. 18v; inv.402, p. 2ov; inv. 403, f. 2or.

62 GAG, Ommelander Archieven, inv. 411, f. 22v.
} 
Barlinckhof. ${ }^{63}$ Typographical analysis suggests that Frans Bronchorst, the stadsdrukker who succeeded Jan Claessen, also printed for the Ommelanders. ${ }^{64}$ The Ommelanders had no qualms approaching printers who usually published their opponent's declarations; this strategy may have been a deliberate attempt to spread the patronage of the Council. The magistrates of Groningen, fighting on home turf within the safety of their walls, were more consistent in their choice of stadsdrukker; but even they sometimes called upon Rembertus Huisman, the States and Ommelander printer after the death of his mother, for the printing of ordinances in the $1670 \mathrm{os}$.

To the printers of Groningen, the Ommelander conflict was a welcome financial windfall. As the Groningen account books reveal, the authorities rewarded them generously. But the print shop could also become a site of the struggle, or worse, a bargaining chip in the conflict. On 8 September 166o, the magistrates of Groningen published an ordinance in which they accused the regents of the Ommelanden of obstructing a recent ruling of the provincial States, aimed at curbing rural (Ommelander) taxation. ${ }^{65}$ The Ommelanders had visited the printer of the States (the widow of Edzard Huisman) and told her not to print any copies of the placard. Given that the widow was also the printer of the Council of Ommelanden, one can imagine that she could easily be persuaded. As usual, however, the Groningers played the same game. On 30 July 1677, the Ommelanders complained to the States General that the magistrates of the city had assaulted a printer who produced a placard for them. They wrote that

A certain individual, a Frisian of birth, but resident in Groningen, who was recently appointed official printer of the Ommelanden, was arrested [by the magistrates] for printing an Ommelander placard, and his equipment and furnishings were confiscated and taken to the city hall, to ruin his livelihood and family. ${ }^{66}$

63 GAG, Ommelander Archieven, inv. 39o, f. 23v; inv. 411, f. 24 r.

64 Compare for example the typography and woodcut initials of a 26 April 1662 Groningen ordinance with a 13 September 1656 Ommelanden broadsheet: De heeren borgemeesteren ende raedt in Groningen, sijnde in ervaeringe gekoomen, hoe dat jonckeren uyt den Omlanden onlanghs in Den Haeghe, aen haere Ho: Mog: hebben voorgedraegen seecker concept nopende d'ampliatie van het Omlander reglement ([Groningen: Frans Bronchorst, 1662]) and Sententie der heeren gecommitteerde richteren ende arbiters der Ommelanden tusschen d'Eems ende Lauwers, gepronuncieert tegens Roeleff Fockens ([Groningen: Frans Bronchorst, 1656]).

65 De heeren borgemeesteren ende raadt in Groningen, doen te weten [Reactie van het bestuur van de stad Groningen op beschuldigingen in een door de Ommelanden uitgevaardigd plakkaat] ([Groningen: s.n., 166o]). 
Rembertus Huisman, the printer affected, must have been shaken by the whole affair. The arrest was a political retaliation, one of the many blows inflicted by the Groningers and Ommelanders upon their opponent. The magistrates quickly released Huisman, however, and returned his possessions. He was, after all, the printer not only of the Ommelanden, but of the States of Groningen. When the conflict subsided, the magistrates would require his services too. When the two parties had come to an informal peace, they once again presented themselves as the united States of Groningen, exercising sovereign rule over all the inhabitants of the province. Their solemn placards and ordinances, printed by Huisman, betrayed nothing of their divisions. This thin veneer of dignity, covering decades of public strife, would have fooled few in Groningen.

\section{Conclusion}

States across early modern Europe frequently attacked one another publicly through placards. From the emergence of the Dutch state in the later sixteenth century, the States General had issued ordinances denouncing the Spanish Habsburg crown, contesting their claims on territory, or appealing to citizens in the Southern Netherlands for assistance in the liberation of their homeland. ${ }^{67}$ The Habsburgs generally responded to such publications in kind. The proclamation of declarations of war, an essential element of early modern politics, also offered authorities opportunities to justify their conduct and highlight the wrongdoings of their enemy. As Helmer Helmers has recently demonstrated, early modern states and diplomats had ample means available to protect their own public reputation and subvert that of their opponents. The statesmen of the Dutch Republic, brought up in a decentralised republican state with a contested political constitution, were certainly not foreign to such tactics: they were 'among the first to develop what we might call an institutionalized public diplomacy', a form of communication which often relied on the technology of the printing press. ${ }^{68}$

\footnotetext{
67 See for some examples, Placcaet, ende ordonnantie van retorsie, der hoogh ende moghende heeren Staten Generael daer by alle commercien met den vyandt werden verboden (Den Haag: weduwe en erfgenamen Hillebrant van Wouw, 1625), USTC 1032818 and Placaet van retorsie, teghen de ongefondeerde pretensien vanden koningh van Spaignen, op het Quartier ende Meyerije van 'sHertogen-bosch (Den Haag: weduwe en erfgenamen Hillebrant van Wouw, 1636), ustc 1019944.

68 Helmers, 'Public diplomacy in Early Modern Europe', p. 407.
} 
In the confederal Dutch Republic, with its plethora of competing jurisdictions, authorities employed similar strategies of communication to resolve their domestic conflicts. The authority of the city councils and provincial States were inextricably tied to perceptions of their performance as guardians of the confederal union. By publishing in print their nominally secret deliberations, letters and resolutions, Dutch authorities offered the public a glimpse into the closed chambers of the States or the city hall. Through this they hoped to embarrass their opponents publicly, forcing them to issue a response or be left with a blemish on their reputation; at the same time they sought to defend their own honour, a task greatly complicated by the appropriation of similar tactics by their opponents. Each advantage could be exploited for gains elsewhere: the demotion of a political rival, concessions of economic privileges, or simply public humiliation. Throughout the seventeenth century, alliances and patronage networks in the Dutch Republic were constantly shifting, and never solidified into defined political parties. ${ }^{69}$ For this reason the magistrates of Groningen and the Council of Ommelanden battled in public for the attention of their peers throughout the Dutch Republic as much as their own citizens.

These communication strategies encouraged a burgeoning print trade. The printers, publishers and booksellers of Groningen were grateful for the patronage of the local authorities, and were happy, in many instances, to cater to both sides of the conflict. Although the printing shop itself could turn into a space of political conflict, the print trade benefited hugely from the communication strategies employed by the regents. The role of printers was also crucial to the amplification of the conflict throughout the Dutch Republic. The circulation of printed declarations from Groningen to The Hague and beyond extended the sense of participation to citizens beyond the immediate confines of the province. This was a battle which was fought not only in the Groningen countryside or market square, but in the bookshops of The Hague, Amsterdam and other cities. In the seventeenth-century Dutch Republic, the conduct of politics had become inseparably tied to the business of books.

69 D.J. Roorda, Partij en Factie. De oproeren van 1672 in de steden van Holland en Zeeland, een krachtmeting tussen partijen en facties (Groningen: Wolters, 1978). 